\title{
KUALITAS MANAJEMEN KEUANGAN PENGERAJIN LUKISAN KACA DI DESA NAGASEPAHA
}

\author{
${ }^{a}$ Ni Made Sri Ayuni, ${ }^{b}$ Ni Wayan Novi Budiasni \\ a,bSekolah Tinggi Ilmu Ekonomi Satya Dharma Singaraja \\ animadesriayuni90@gmail.com
}

\begin{abstract}
ABSTRAK
Kualitas Manajemen Keuangan Pengerajin Lukisan Kaca di Desa Nagasepaha. Penelitian ini merupakan penelitian kualitatif untuk meneliti pengelolaan keuangan pengerajin lukisan kaca di Desa Nagasepaha. Penelitian bertujuan ingin mengetahui bagaimana pengerajin mengelola keuangan dilihat dari perencanaan keuangan, pencatatan keuangan, pelaporan keuangan dan pengendalian keuangan.Sehingganantinya hasil penelitian ini mampumemberikan suatu kesimpulan tentang pengelolaan keuangan untuk pengerajin lukisan kaca di Desa Nagasepaha. Penelitian ini mengunakan pendekatan kualitatif dengan metode studi kasus. Data yang dianalisa adalah hasil wawancaradenganpengerajinlukisan kaca. Hasil penelitian menujukan bahwa Pengerajin sudah mampu mengelola keuangan dilihat dari perencanaan akan tetapi pengerajin belum melakukan pencatatan, pelaporan dan pengendalian keuangan sesuai dengan standar akuntansi dan manajemen keuangan. Mengingat belakang pendidikan dan minimnya pengetahuan terhadap pencatatan,pelaporan dan pengendalian keuangan nantinya pengerajin dapat mengikuti pelatihan pencatatan keuangan sesuai dengan standar akuntansi.Diharapkan nantinya semua pengerajin bisa mengunakan kaidah-kaidah pencatatan yang terstruktur.
\end{abstract}

Katakunci:pengelolaan keuangan, lukisan kaca, Nagasepaha

\begin{abstract}
Quality of Financial Management of Glass Painting Craftsmen in Nagasepaha Village. This research is a qualitative research to examine the financial management of glass painting craftsmen in Nagasepaha Village. This study aims to find out how craftsmen manage finances seen from financial planning, financial records, financial reporting and financial control. So that later the results of this study are able to provide a conclusion about financial management for glass painting craftsmen in Nagasepaha Village. This research uses a qualitative approach with a case study method. The data analyzed is the result of interviews with glass painting craftsmen. The results of the study indicate that craftsmen are able to manage finances seen from planning but craftsmen have not recorded, reported and controlled finances in accordance with accounting standards and financial management. Given the background of education and the lack of knowledge of financial recording, reporting and control later, craftsmen will be able to take part in financial recording training in accordance with accounting standards. It is hoped that later all craftsmen will be able to use structured recording rules.
\end{abstract}

Keywords:Financial management, glass painting, Nagasepaha 


\section{PENDAHULUAN}

Keadaan ekonomi saat ini semakin sulit dan tentunya menuntut kita bekerja lebih keras untuk bertahan hidup. Kedepannya kita sebagai mahkluk ekonomi tidak akan cukup jika hanya mengandalkan satu penghasilan saja, sebab keperluan yang semakin banyak dan harga barang makin meningkat. Kondisi demikian memaksa kita untuk bertahan dengan berinovasi membuka peluang usaha yang baru untuk memaksimalkan penghasilan. Solusi yang bisa ditempuh ialah dengan berwirausaha. (Radas, 2009) menyatakan usaha kecil dianggap mesin pertumbuhan ekonomi yang mampu merangsang pergerakan ekonomi dan lapangan kerja.

Adanya inovasi maupun inovasi produk merupakan salah satu keunggulan kompetitif yang bisa digunakan sebagai salah satu strategi oleh perusahaan untuk memenuhi permintaan pasar (Prakosa, 2005).Dimana suatu inovasi dapat berperan penting dalam menambah nilai dari suatu produk yang dibuat oleh suatu pelaku usaha. Maka dari itu inovasi disini sangat perlu dipertimbangkan bagi pelaku usaha untuk membuat usahanya lebih maju, tidak hanya berbicara mengenai inovasi akan tetapi ada hal lain yang perlu juga diperhatikan yaitu orientasi pasar agar usaha bisa mencapai keunggulan bersaing yang berkelanjutan.

Dilihat dari perkembangan yang ada, gaya hidup yang semakin konsumtif menyebabkan terciptanya inovasi-inovasi yang lebih kreatif. Hal ini dibuktikan dengan, semakin maraknya produk dengan varian-varian baru dengan tujuan menarik minat konsumen. Misalnya, berbagai macam kreatifitas seni kerajinan tangan yang dihasilkan oleh para pengerajin di Bali. Keunikan produk sebagai hasil inovasi temporer membuat persaingan pasar lebih maksimal (McDaniel, 2002) bahkan suatu inovasi merupakan kunci keunggulan bersaing suatu perusahaan (Urbancova, 2013). Selanjutnya, (Devira, 2019) megungkapkan UMKM di Desa Nagasepaha harus meningkatkan inovasi produk dan menargetkan orientasi pasar yang baik,sehingga tujuan untuk mencapai keunggulan bersaing berkelanjutan.

Pemerintah Kabupaten Buleleng sangat mendukung keberlangsungan UMKM di Kabupaten Buleleng. Bertolak pada data Dinas Koperasi dan UMKM Provinsi Bali, jumlah UMKM di Kabupaten Buleleng mencapai 34.552 pengusaha UMKM dan secara keseluruhan UMKM di Provinsi Bali berkontriusi sebesar 2.394,5 Triliun terhadap Produk Domestik Bruto (PDB) Indonesia atau mencapai 65\% (Sukarsa, 2020). Namun, kondisi pandemi covid 19 memberikan dampak pada seluruh sektor perekonomian, termasuk sektor UMKM. Ketidakstabilan ekonomi berimbas pada penurunan omset UMKM, hal ini sangat mengkhawatirkan, sebab UMKM memiliki peranan yang sangat penting dalam hal pertumbuhan perekonomian sekaligus penyerapan tenaga kerja (Sukarsa, 2020). Oleh karena peranan yang sangat penting, perlu adanya upaya menjaga keberlangsungan UMKM di Kabupaten Buleleng.

Pandemi COVID 19 melumpuhkan banyak persendian ekonomi masyarakat. Salah satu yang ikut terdampak adalah usaha kerajinan khas dari Desa Nagasepaha, lukisan wayang kaca. Dampak pandemi COVID 19 merontokan usaha kerajianan lukisan kaca. Daya beli masyarakan menjadi turun drastis. Sebelum adanya pandemi pengerajin lukisan kaca mampu menjual lukisan kaca sebanyak 20 sampai dengan 40 buah dalam setiap bulannya. Akan tetapi dimasa pandemi ini membuat pengerajin kesulitan memasarkan produknya dikarena kegiatan seperti pameran ditiadakan, pengerajin masih memasarkan produknya menggunakan system door to door.

Seringkali dalam menjalankan usaha mikro, pengelolaan keuangan kurang diperhatikan, terlebih pengelolaan keuangan yang berdasarkan aturan-aturan yang benar dalam ilmu akuntansi. Kondisi ini terjadi dikarenakan pengetahuan pengelola usaha mikro yang masih terbatas dan pemahaman terhadap ilmu akuntansi yang kurang memadai. (Setyorini, 2010) mengemukakan bahwa pengelolaan keuangan sebagai faktor penting dalam memajukan perusahaan. Sebab, ilmu akuntansi yang diterapkan dalam pengelolaan keuangan mampu menghasilkan laporan keuangan yang akan memberikan informasi untuk pengambilan keputusan dalam manajemen perusahaan. Selain itu, (Ediraras, 2010) menyatakan bahwa suatu pengelolaan keuangan yang baik ialah kemampuan perusahaan untuk memberikan informasi keuangan secara akurat dan transparan. Hal ini akan berdampak positif pada 
kemajuan usaha UMKM tersebut. Apabila pengelolaan keuangan bisa dilaksanakan dengan baik, maka semakin besar peluang kemajuan perusahaan/usaha tersebut.

Sesuai dengan fenomena pentingnya pengelolaan keuangan yang baik pada suatu UMKM, maka penulis memutuskan untuk mengkaji permasalah tersebut dalam sebuah penelitian tentang pengelolaan keuangan pada pengerajin Lukisan Kaca Desa Nagasepaha. Hasil dari penelitian ini dapat dijadikan sebagai bahan atau solusi alternartif pengelolaan keuangan oleh pengerajin Lukisan Kaca Desa Nagasepaha. Adapun judul yang penelitian ini adalah "Kualitas Manajemen Keuangan Pengerajin Lukisan Kaca di Desa Nagasepaha".

\section{KAJIAN LITERATUR}

\section{Manajemen Keuangan}

Berdasarkan beberapa pendapat para ahli disampaikan bahwa, Manajemen Keuangan merupakan proses kegiatan yanga dilakukan perusahaan atau organisasi dalam memperoleh dana, bagaimana mengelola dana agar dana tersebut menghasilan keuntungan. Perusahaan harus memiliki cara agar dapat memaksimalkan kekayaan baik itu aktiva lancar dan aktiva tetap yang dimiliki. Mengelola keuangan perusahaan akan dapat menjaga eksistensi saat ini, maupun dimasa akan datang. Manajemen keuangan juga berfungsi untuk mempertimbangan dalam berinvestasi berdasarkan hasil analisa yang relevan yang nantinya mentukan apakah perusahaan menambah investasi, menetapkan investasi, atau mengurangi investasi. Investasi yang tepat sangat penting bagi perusahaan mengigat keputusan pendanaan akan menentukan seberapa besar perusahaan akan mendapatkan keuntungan dari dana yang diinvestasikan.Semua perusahaan pasti mengharapkan laba yang maksimal dari investasi yang dilakukan maka dari itu diperlukan suatu keputusan manajemen mengingat perusahaan harus paham sumber pendanaan yang berasal dari dalam perusahaan (modal sendiri) atau dari luar perusahaan (utang). Memilih sumber pendanan sangat penting mengingat akan ada biaya-biaya yang nantinya akan dikeluarkan dalam melakukan investasi. Bagi perusahaan memilih solusi biaya yang paling terendah mengharapkan mendapatkan laba maksimal dan tetep menjaga kualitas dari produk atau pun jasa yang dihasilkan. Diperlukan orang yang tepat dan paham mengenai fungsi dari manajemen keuangan. Semua bagian dari perusahaan akan berkaitan dengan manajemen keuangan.(Ross, 2000),(Cornett, 2009),(Kasmir, 2012), dan (James C, 2012).

\section{Pengelolaan Keuangan Manajemen Keuangan}

Semua perusahaan pasti mempunyai misi meningkatakan keuntungan secara maksimal tentunya untuk mencapai misi tersebut perlu dilakuakan beberapa strategi yang salah satunya bisa dilakuakan yaitu pengelolaan keuangan manajemen keuangan harus dilakukan secara baik dan benar disesuikan dengan prosedur yang dimiliki perusahaan diharapkan nanti dana yang dimiliki dapat digunakan secara efektif dan efesien. Dasar perusahaan mengelolaan manajemen keuangan bisa dari analisa yang mendalam dari keadaan keuangan perusahaan hal ini berfungsi untuk pengambilan suatu keputusan berdasarkan data keuangan di masa lalu, sekarang dan bisa merencanakan keuangan di masa yang akan datang. Seorang manajer keuangan harus mampu menganaliasa keadaan keuangan perusahaan yang nantinya akan dijadikan bahan pertimbangan dalam pengambilan suatu keputusan untuk perusahaan (Sartono, 2001),dan (Sutrisno, 2003).

Pengelolaan keuangan terdiri dari empat yaitu perencanaan perusahaan memilah dan melilih beberapa alternatif yang dimiliki perusahaan dimana sasaran keuagan yang diinginkan perusahaan tercapai baik itu perencanaan jangka pendek, perencanaan jangka menengah, dan perencanaan panjang. Dalam manajemen keuangan pencatatan menjadi hal yang sangat penting untuk mengingat transkasi yang terjadi selama periode tertentu. Pencatatan harus dilakukan secara sistematis dan terperinci untuk meminimalisasi kesalahan pencatatan keuangan yang nantinya bisa merugikan perusahaan. Selanjutnya setelah melakukan pencatatan perusahaan perlu melakukan pelaporan keuangan dimana perusahaan perlu melaporkan laporan keuanga seperti laporan neraca, laporan laba/rugi, 
laporan perubahan modal dan laporan arus kas.Terakhir perlu dilakukan pengendalian dari semua kegiatan yang sudah dilaksanakan perusahanan melakukan pengukuran dan bahan evaluasi untuk kegiatan selanjutnya. Diharapkan dengan adanya evaluasi mampu meminimalisasi kerugian perusahaan apabila terjadi kesalahan baik yang disengaja atau pun tidak adanya perbaikan untuk mencapai misi yang sudah disepakati bersama (Kuswadi, 2005).

\section{METODE}

Penelitian ini berlokasi di Desa Nagasepaha dimana penelitian ini mengunakan metode kualitatif. Peneliti memilih pengerajin lukisan kaca sebagai informan utama dimana hasil wawancara akan diuji validasinya mengunakan metode trianggulasi sumber.Review informan dilakukan pada waktu peneliti sudah mendapatkan data yang cukup lengkap dan berusaha menyusun sajian datanya walaupun mungkin masih belum utuh dan menyeluruh, unit-unit laporan tersebut dikomunikasikan dengan informannya. Hal itu dilakukan untuk mengetahui apakah laporan yang disusun merupakan pernyataan atau deskripsi sajian yang mereka setujui. Data yang telah dianalisis oleh peneliti sehingga menghasilkan suatu kesimpulan selanjutnya dimintakan kesepakatan (member check) dengan tiga sumber data tersebut.

Verifikasi hasil dari kesimpulan melalui member chack dengan informan. Mengadakan kesepakatan dengan informan bahwa data yang telah diterima sudah sesuai dengan hasil wawancara. Selanjutnya data sudah benarmaka data sudah dianggap valid, maka peneliti perlu melakukan diskusi dengan pemberi data agar penafsiran akan data yang diperoleh dapat disepakati.

Analisis data dalam penelitian kualitatif biasanya dilakukan bersamaan dengan proses pengumpulan data sampai diperoleh suatu kesimpulan. Menurut Miles dan Huberman dalam (Sugiyono, 2011) mengemukakan bahwa aktivitas dalam analisis data kualitattif dilakukan secara terus menerus sampai tuntas, sehingga datanya sudah jenuh. Aktivitas dalam analisis data,yaitu data reduction, data display, dan cuclusion drawing/verification.

\section{HASIL DAN PEMBAHASAN}

\section{Kualitas Manajemen Keuangan (Pengelolaan Keuangan)}

A. Perencanaan Keuangan

Dalam wawancara dengan pengerajin mengenai perolehan modal yang dimiliki oleh Pengerajin Lukisan Kaca, didapatkan dari tabungan pribadi dan pinjaman. Setelah memiliki cukupmodal, maka keputusan investasi mengenai modal yang telah dimilikinya adalahmenggunakan sebagian modal untuk pembelian aset tetap seperti membeli meja, kursi untuk membuat lukisan kaca. Selain itu pengerajin juga membangun tempat produksi yang lebih layak dan sebagian lagi untuk modal kerja seperti dipergunakan untuk membeli bahan baku dan upah untuk pengerajin lukisan kaca.

Menurut (Ucig, 2020) perencanaan produksi yang tepat akan membantu perusahaan untuk menerapkan efisiensi.Menurut (Waode, 2018) setiap bisnis mutlak perlu memiliki pengelolaan manajemen modal kerja dan perencanaan keuangan yang baik. Manajemen modal kerja itu sendiri memiliki fungsi sebagai pembiayaan operasional perusahaan seharihari seperti pembayaran gaji dan upah bagi karyawan, pembelian bahan baku, pembayaran ongkos angkutan, pembayaran hutang yang telah jatuh tempo, dan lain sebagainya. Modal kerja yang telah dikeluarkan itu diharapkan akan dapat kembali lagi masuk dalam perusahaan dalam waktu yang singkat melalui hasil penjualan produksinya.

Pengerajin diharapkan mampu mengelola modal kerja yang berasal dari penjualan lukisan kaca yang nantinya akan dapatdigunakan untuk membiayai kegiatan operasional selanjutnya. Modal kerja ini akan terus berputar setiap periodenya di dalam perusahaan. Dalam penggunaan anggaran pengerajin harus dapat memisahkan uang pribadi dengan 
modal usaha agar pengerajin dapat mengetahui dengan baik keuangan yang dimiliki perusahaan sebenarnya.

\section{B.Pencatatan Keuangan}

Pada wawancara dengan pengerajin lukisan kaca mengatakan bahwa hanya melakukan pencatatan sederhana secara manual kas masuk dan kas keluar karena keterbatasan pengetahuan dari pengerajin mengenai pencatatan keuangan SAK namun pengerajin membuat catatan sederhana tersebut sudah cukup karena catatan hanya hanya dipahami oleh pengerajin. Ini menguatkan bahwa Pengerajin Lukisan kaca belum memiliki pencatatan keuangan yang sesuai standar akuntansi. Hal ini sesuai dengan penelitian (Rangga, 2017) dengan judul Makna Penerapan Pencatatan Keuangan Bagi Pelaku Usaha Kecil Menengah (Ukm) ; (Studi Kasus Pada Depot Pak Djo Di Surabaya) Dari hasil analisis data dapat disimpulkan bahwa pemilik UKM masih kurang dalam pemahaman pencatatan keuangan dan model pencatatannya masih sederhana hanya sebatas pada pencatatan cash flow saja.

Selanjutnya hasil penelitian (Falih, Muhammad Sabiq Hilal Al, 2019) yang berjudul "Pengelolaan keuangan dan pengembangan usaha pada usaha mikro kecil menengah (study kasus pada UMKM Madu Hutan Lestari Sumbawa)"menyatakan bahwa manajemen keuangan yang diterapkan oleh UMKM masih sangat sederhana yakni hanya ada pencatatan uang masuk dan uang keluar dan masih belum menggunakan kaidah-kaiadah pencatatan arus kas yang baik dan benar.Demikian halnya dengan penelitian (Lusy, 2019) tentang "Penerapan Laporan Keuangan Usaha Mikro Kecil Dan Menengah (UMKM) Di Kecamatan Pahandut Kota Palangka Raya" Hasil dari penelitian ini menunjukkan bahwa pemahaman pelaku Usaha Mikro, Kecil, dan Menengah (UMKM) terhadap pencatatan laporan keuangan di Kecamatan Pahandut kota Palangka Raya terbilang masih rendah.

Melihat dari latar belakang pendidikan dan minimnya pengetahuan terhadap pencatatan keuangan nantinya pengerajin dapat mengikuti pelatihan pencatatan keuangan sesuai dengan standar akuntansi.Diharapkan nantinya semua pengerajin bisa mengunakan kaidah-kaidah pencatatan yang terstruktur.

\section{C.Pelaporan Keuangan}

Laporan keuangan merupakan hasil akhir proses akuntansi. Kinerja sebuah usaha dapat di nilai berdasarkan laporan yang dibuat secara periodik, yang bisa dilakukan pelaporanya setiap periode tertentu. Berdasarkan hasil wawancara dan observasi peneliti melihat bahwapengerajin lukisan kaca belum membuat laporan keuangan seperti neraca, laporan laba/rugi, dan perubahan modal dikarenakan pengerajin belum paham secara menyeluruh tentang laporan keuangan.

Pengertian laporan keuangan berdasarkan Standar Akuntansi Keuangan (SAK) adalah sebagai berikut: laporan keuangan merupakan bagian dari proses pelaporan keuangan. Laporan keuangan merupakan alat yang digunakan untuk mengkomunikasikan informasi keuangan dari suatu perusahaan kepada pihak-pihak yang berkepentingan dengan eksistensi perusahaan. Tujuan laporan keuangan adalah penyajian informasi mengenai posisi keuangan (financial position), kinerja keuangan (financial performance) dan arus kas (cash flow) dari entitas yang sangat berguna untuk membuat keputusan ekonomis dari para penggunanya. Demikian halnya dengan penelitian (Lusy, 2019) tentang "Penerapan Laporan Keuangan Usaha Mikro Kecil Dan Menengah (UMKM) Di Kecamatan Pahandut Kota Palangka Raya" Hasil dari penelitian ini menunjukkan bahwa pemahaman pelaku Usaha Mikro, Kecil, dan Menengah (UMKM) terhadap pencatatan laporan keuangan di Kecamatan Pahandut kota Palangka Raya terbilang masih rendah.

Selajutnya jika pengerajin lukisan kaca mampu membuat laporan keuangan maka pengerajin tidak akan bingung menghitung aktiva, pasiva, pendapatan dan biaya yang yang dimiliki oleh pengerajin. Laporan keuangan bisa dijadikan alat untuk menginformasikan keadaan keuangan yang sebenarnya. 


\section{D.Pengendalian keuangan}

Dalam Pengendalian keuangan peneliti mendapatkan informasi dari pengerajin Lukisan Kaca tidak memiliki regulasi keuangan yang jelas dan tidak melakukan audit keuangan. Namun yang dilakukan oleh pengerajin dalam pengendalian keuangan adalah mengarsipkan nota penjualan, nota pembelian bahan baku dan upah pengerajin. Seperti telah disampaikan oleh pengerajin dalam wawancara bahwa tidak memiliki aturan tertentu dalam keuangan maka perusahaan ini tidak memiliki prosedur penarikan kas keluar dikarenakan tidak ada bagian keuangan dan administrasi. Pada saat wawancara pengerajin juga mengatakan tidak merasa perlu adanya aturan tertentu karena semua mengenai administrasi karena keuangan dipegang sendiri. Ini menunjukkan pengendalian keuangan pengerajin lukisan kaca masih belum maksimal dilakukan.

Hasil ini sesuai dengan penelitian (Yustian Free, 2017) mengenai "Pengelolaan Keuangan Usaha Kecil Mikro Menengah Pada Asosiasi Batik Sleman". Hasil penelitian menunjukkan bahwa penerapan pengendalian pada pengelolaan keuangan UMKM masih rendah bila dibandingkan dengan indikator lain, UMKM ini belum mempertimbangkan perlu adanya pengendalian. Selanjutnya hasil penelitian Novialumi berjudul " Kualitas Manajemen Keuangan Usaha Mikro Kecil Menengah (UMKM) hasil menunjukan bahwa indikator pengendalian keuangan, pelaku butik umumnya sulit untuk tidak menggunakan uang perusahaan menjadi uang pribadi dari segi kuantitatif pelaku usaha butik umumnya membutuhkan hutang untuk menjalankan usahanya. Menurut (Hani, 2011) pengendalian digunakan sebagai penjamin bahwa rencana telah dilaksanakan sesuai dengan perencanaan.

Diharapkan kedepannya pengerajin mampu mengetahui pemasukan dan pengeluaran uang yang belum dikelola dengan baik yangmenimbulkan kerugian dapat terjadi diwaktu yang akan datang, sedangkan pengelolaan pemasukan dan pengeluaran uang yang baik dapat membantu pengerajin membuat perencanaan jangka pendek maupun jangka panjang untuk mencapai tujuan.

\section{SIMPULAN}

Pengerajin diharapkan mampu mengelola keuangandalam penggunaan anggaran pengerajin harus dapat memisahkan uang pribadi dengan modal usaha agar pengerajin dapat mengetahui dengan baik keuangan yang dimiliki perusahaan sebenarnya. Melihat dari latar belakang pendidikan dan minimnya pengetahuan terhadap pencatatan keuangan nantinya pengerajin dapat mengikuti pelatihan pencatatan keuangan sesuai dengan standar akuntansi.

Diharapkan nantinya semua pengerajin bisa mengunakan kaidah-kaidah pencatatan yang terstruktur.Selajutnya jika pengerajin lukisan kaca mampu membuat laporan keuangan maka pengerajin tidak akan bingung menghitung aktiva, pasiva, pendapatan dan biaya yang yang dimiliki oleh pengerajin. Laporan keuangan bisa dijadikan alat untuk menginformasikan keadaan keuangan yang sebenarnya.

\section{REFERENSI}

Cornett, D. (2009). Earnings Management, Corporate Governance, and True Financial Performance.

Devira, N. M. \& S. (2019). Peran Inovasi Produk dan Orientasi Pasar dalam Mencapai Keunggulan Bersaing Berkelanjutan melalui Kinerja Pemasaran Pada UKM Di Desa Nagasepaha.

Ediraras, D. (2010). Akuntansi dan Kinerja UMKM. Jurnal Ekonomi Bisnis, 5.

Falih, Muhammad Sabiq Hilal Al, dkk. (2019). Pengelolaan keuangan dan pengembangan usaha pada usaha Mikro kecil menengah (studi kasus pada umkm madu hutan Lestari sumbawa). Jurnal Manajemen Dan Bisnis. 
Hani, H. (2011). Manajemen (Kedua). Yogyakarta: BPFE.

James C, H. (2012). Prinsip-Prinsip Manajemen Keuangan (Edisi 13). Jakarta: Salemba Empat.

Kasmir. (2012). Analisis Laporan Keuangan. Jakarta: PT. Raja Grafindo Persada.

Kuswadi. (2005). Cara Mudah Memahami Angka dan Manajemen Keuangan bagi Orang Awam. Jakarta: Elex Media Komputindo.

Lusy. (2019). Penerapan Laporan Keuangan Usaha Mikro Kecil dan Menengah (UMKM) Di Kecamatan Pehandut Kota Palangka Raya.

McDaniel, B. . (2002). Entrepreneurship and Innovation: An Economic Approach. Newyork: M.E.Sharpe Inc.

Prakosa, B. (2005). Pengaruh Orientasi Pasar, Inovasi dan Orientasi Pembelajaran terhadap Kinerja Perusahaan untuk Mencapai Keunggulan Bersaing (Studi Empiris pada Industri Manufaktur Di Semarang). Jurnal Studi Manajemen Dan Organisasi.

Radas, S. \& B. (2009). No Title. The Antecedentsof SMEs Innovativeness in AnEmerging Transition Economy, 438-450.

Rangga, A. . (2017). Makna Penerapan Pencatatan Keuangan Bagi Pelaku Usaha Kecil Menengah (UKM) Studi Kasus Pada Depot Pak Djo Di Surabaya.

Ross, D. (2000). Modern Financial Corporate. Mc Graw Hill.

Sartono, A. (2001). Manajemen Keuangan Teori dan Aplikasi. Yogyakarta: BPFE.

Setyorini, D. (2010). Pelatihan Akuntansi UMKM bagi Usaha Mikro Kecil Menengah (UMKM) untuk Meningkatkan Kinerja Keuangan Perusahaan Yogyakarta.

Sugiyono. (2011). Metode Penelitian Administrasi. Bandung: Alfabeta.

Sukarsa, I. W. (2020). Adaptasi UMKM Di Bali. Bali Post, p. 1.

Sutrisno. (2003). Manajemen Keuangan (Teori, Konsep, dan Aplikasi). Yogyakarta: EKONISIA.

Ucig. (2020). Cara Membuat Perencanaan Produksi yang Tepat.

Urbancova, H. (2013). Competitive Advantage Achievment Through Innovation and Knowledge.

Waode, L. dan. (2018). Produktivitas Sumber Daya Manusia dalam Manajemen Keuangan. Bandung: Pekbis Jurnal Universitas Padjajaran.

Yustian Free, I. (2017). Pengelolaan Keuangan Usaha Kecil Mikro Menengah pada Asosiasi Batik Sleman. Yogyakarta: Universitas Sanata Dharma Yogyakarta. 